Article

\title{
Effects of N/S Molar Ratio on Product Formation in Psychrophilic Autotrophic Biological Removal of Sulfide
}

\author{
Michal Sposob * (D), Rune Bakke (D) and Carlos Dinamarca \\ Department of Process, Energy and Environmental Technology, University College of Southeast Norway, \\ Kjølnes Ring 56, 3918 Porsgrunn, Norway; rune.bakke@usn.no (R.B.); carlos.dinamarca@usn.no (C.D.) \\ * Correspondence: michal.sposob@usn.no; Tel.: +47-4863-2389
}

Received: 13 March 2017; Accepted: 27 June 2017; Published: 29 June 2017

\begin{abstract}
The excessive $\mathrm{H}_{2} \mathrm{~S}$ presence in water and wastewater can lead to corrosion, toxicity, and biological processes inhibition-i.e., anaerobic digestion. Production of $\mathrm{H}_{2} \mathrm{~S}$ can occur in psychrophilic conditions. Biological removal of $\mathrm{HS}^{-}$by addition of $\mathrm{NO}_{3}{ }^{-}$as an electron acceptor under psychrophilic $\left(10^{\circ} \mathrm{C}\right)$ conditions in a continuous flow experiment is evaluated here. Four different N/S molar ratios- $0.35,0.40,0.60$, and 1.30 - were tested in an expanded granular sludge bed (EGSB) reactor. Samples were analyzed daily by ion chromatography. Efficient psychrophilic $\mathrm{HS}^{-}$removal with sulfur products oxidation control by $\mathrm{NO}_{3}{ }^{-}$supply is documented. The highest $\mathrm{HS}^{-}$removal was obtained at N/S $=0.35$ and $1.30(89.1 \pm 2.2$ and $89.6 \pm 2.9 \%)$. Removal of HS $^{-}$was less at mid-N/S with the lowest value $(76.9 \pm 2.6 \%)$ at $\mathrm{N} / \mathrm{S}=0.60 . \mathrm{NO}_{3}{ }^{-}$removal remained high for all $\mathrm{N} / \mathrm{S}$ ratios. N/S molar ratio influenced the sulfur products distribution with less $\mathrm{S}^{0}$ and increase in $\mathrm{SO}_{4}{ }^{2-}$ effluent concentration with increasing $\mathrm{N} / \mathrm{S}$ ratio. Oxidation of $\mathrm{HS}^{-}$and accumulated $\mathrm{S}^{0}$ occurred simultaneously at $\mathrm{N} / \mathrm{S}$ ratios $>0.35$. The observations are explained by culture flexibility in utilizing available resources for energy gain.
\end{abstract}

Keywords: autotrophic denitrification; elemental sulfur recovery; psychrophilic conditions; sulfate production; sulfide removal; N/S ratio impact

\section{Introduction}

Nitrate $\left(\mathrm{NO}_{3}{ }^{-}\right)$and sulfide $\left(\mathrm{H}_{2} \mathrm{~S}\right)$ are present in many kinds of wastewater. Their removal is necessary due to their negative environmental and economic impact-i.e., increase of maintenance costs in anaerobic digesters or wastewater treatment plants. Presence of $\mathrm{H}_{2} \mathrm{~S}$ can lead to corrosion, human toxicity, and biological process inhibition [1]. It has been reported that concentrations of dissolved HS ${ }^{-}$ in the $100-800 \mathrm{mg} / \mathrm{L}$ range can inhibit anaerobic digestion [2]. Additionally, the presence of $\mathrm{NO}_{3}{ }^{-}$can inhibit volatile fatty acids (VFAs) production, methanogens, and consequently methane production [3].

Due to the wide diversity of sulfur reducing bacteria (SRB) the production of $\mathrm{H}_{2} \mathrm{~S}$ can occur also in psychrophilic conditions [4]. The possibility to remove $\mathrm{H}_{2} \mathrm{~S}$ in psychrophilic conditions by harvesting elemental sulfur $\left(\mathrm{S}^{0}\right)$ out of the process line seems to be an interesting opportunity. Many waters and wastewaters are characterized by their low temperatures, especially in cold climates and winter conditions (e.g., Nordic countries). Production of $S^{0}$ at low temperatures can become important since heating up to mesophilic conditions can be prohibitively expensive.

$\mathrm{NO}_{3}{ }^{-}$and $\mathrm{HS}^{-}$can be removed simultaneously by sulfide oxidizing bacteria (SOB), where $\mathrm{NO}_{3}{ }^{-}$ serves as an electron acceptor and $\mathrm{HS}^{-}$as an electron donor. Simultaneous removal of $\mathrm{NO}_{3}{ }^{-}$and $\mathrm{HS}^{-}$ has been studied frequently in auto- and heterotrophic conditions but to our knowledge, nothing was published on continuous flow EGSB at low temperatures and at different $\mathrm{N} / \mathrm{S}$ ratios. The simultaneous presence of $\mathrm{NO}_{3}{ }^{-}$and $\mathrm{HS}^{-}$in wastewaters is uncommon. Thus, in terms of applicability of the 
described process, typically $\mathrm{NO}_{3}{ }^{-}$needs to be added to remove $\mathrm{HS}^{-}$from contaminated water. The usage of $\mathrm{NO}_{3}{ }^{-}$as an electron acceptor for $\mathrm{HS}^{-}$removal can be more cost-effective than $\mathrm{O}_{2}$, which can also be used in biological $\mathrm{HS}^{-}$oxidation. $\mathrm{NO}_{3}{ }^{-}$has high solubility and can be added at lower costs than $\mathrm{O}_{2}$ [5].

The simultaneous biological removal of $\mathrm{NO}_{3}{ }^{-}$and $\mathrm{HS}^{-}$can lead to different final products in terms of $\mathrm{HS}^{-}$oxidation degree depending on relative molar ratio between $\mathrm{NO}_{3}{ }^{-}$and $\mathrm{HS}^{-}(\mathrm{N} / \mathrm{S}$ ratio), while $\mathrm{NO}_{3}{ }^{-}$is reduced to nitrogen gas $\left(\mathrm{N}_{2}\right)$. Based on theoretical considerations, including both anabolism and catabolism, two different key N/S ratios can be distinguished: 0.35 and 1.30 [6]. At $\mathrm{N} / \mathrm{S}=0.35$ the main final product is $\mathrm{S}^{0}$ where for 1.30 it is $\mathrm{SO}_{4}{ }^{2-} . \mathrm{N} / \mathrm{S}=1.30$ requires four-times more $\mathrm{NO}_{3}{ }^{-}$than at $\mathrm{N} / \mathrm{S}=0.35$ for mainly $\mathrm{S}^{0}$ production. Mixed products composition occurs at feed ratios between these two values [7]. Previously published batch and continuous flow experiments were focused on appropriate electron donor (reduced sulfur compounds), C/N/S ratios, reactor configurations, and/or pH conditions at mainly mesophilic conditions [8-11]. Psychrophilic conditions are rarely studied $[8,12,13]$, but it has been reported that the removal of $\mathrm{NO}_{3}{ }^{-}$decreases at temperature $<15{ }^{\circ} \mathrm{C}$ [14]. Efficient $\mathrm{NO}_{3}{ }^{-}$removal using thiosulfate $\left(\mathrm{S}_{2} \mathrm{O}_{3}{ }^{2-}\right)$ as an electron donor has, however, been observed at $3{ }^{\circ} \mathrm{C}$ [13] and efficient $\mathrm{NO}_{3}{ }^{-}$removal at $10{ }^{\circ} \mathrm{C}$ with $\mathrm{HS}^{-}$as an electron donor is reported [15].

The objective of this study is to evaluate effects of different N/S ratios as a strategy to control sulfur product distribution in a continuous flow expanded granular sludge bed (EGSB) reactor at $10^{\circ} \mathrm{C}$.

\section{Materials and Methods}

\subsection{Inoculum and Enrichment}

The inoculum was taken from an up-flow anaerobic sludge blanket (UASB) methanogenic reactor treating pulp and paper industry wastewater at Norske Skog Saugbrugs, Halden, Norway. The EGSB reactor was inoculated with $0.25 \mathrm{~L}$ of sludge, which had a total solid content of $59.9 \mathrm{~g} / \mathrm{L}$ with an $86 \%$ organic fraction. Imposed lithoautotrophic conditions caused no methane production while sulfur compounds were produced. The data set evaluated here is from an experiment carried out as a continuation study of temperature impact (temperature range $10-25{ }^{\circ} \mathrm{C}$ ) on sulfur products distribution at constant feed N/S ratio [15].

\subsection{Synthetic Wastewater}

The EGSB reactor synthetic feed contained $\mathrm{Na}_{2} \mathrm{~S} \cdot 9 \mathrm{H}_{2} \mathrm{O}(3.12 \mathrm{mM} \mathrm{S} / \mathrm{L})$ with $\mathrm{NaHCO}_{3}$. Potassium phosphate was used as a buffer. Nitrate, which acted as an electron acceptor was supplied at different concentrations 1.08, 1.25, 1.87, and $4.05 \mathrm{mM} \mathrm{NO}_{3}{ }^{-} / \mathrm{L}$ giving $\mathrm{N} / \mathrm{S}$ ratios $0.35,0.40,0.60$, and 1.30, respectively (Table 1). Nitrate feed contained also the following stock solutions: (A) $\mathrm{NH}_{4} \mathrm{Cl}(10 \mathrm{~g} / \mathrm{L})$, $\mathrm{MgCl}_{2} \cdot 6 \mathrm{H}_{2} \mathrm{O}(10 \mathrm{~g} / \mathrm{L}), \mathrm{CaCl}_{2} \cdot 2 \mathrm{H}_{2} \mathrm{O}(10 \mathrm{~g} / \mathrm{L}) ;(\mathrm{B}) \mathrm{K}_{2} \mathrm{HPO}_{4}(300 \mathrm{~g} / \mathrm{L}) ;(\mathrm{C}) \mathrm{MnSO}_{4} \cdot \mathrm{H}_{2} \mathrm{O}(0.04 \mathrm{~g} / \mathrm{L})$, $\mathrm{FeSO}_{4} \cdot 7 \mathrm{H}_{2} \mathrm{O}(2.7 \mathrm{~g} / \mathrm{L}), \mathrm{CuSO}_{4} \cdot 5 \mathrm{H}_{2} \mathrm{O}(0.055 \mathrm{~g} / \mathrm{L}), \mathrm{NiCl}_{2} \cdot 6 \mathrm{H}_{2} \mathrm{O}(0.1 \mathrm{~g} / \mathrm{L}), \mathrm{ZnSO}_{4} \cdot 7 \mathrm{H}_{2} \mathrm{O}(0.088 \mathrm{~g} / \mathrm{L})$, $\mathrm{CoCl}_{2} \cdot 6 \mathrm{H}_{2} \mathrm{O}(0.05 \mathrm{~g} / \mathrm{L}), \mathrm{H}_{3} \mathrm{BO}_{3}(0.05 \mathrm{~g} / \mathrm{L})$; (D) 10 times concentrated vitamin solution [16]. $\mathrm{HNO}_{3}$, stock solutions A $(10 \mathrm{~mL} / \mathrm{L}), \mathrm{B}(2 \mathrm{~mL} / \mathrm{L}), \mathrm{C}(2 \mathrm{~mL} / \mathrm{L})$, and $\mathrm{D}(1 \mathrm{~mL} / \mathrm{L})$ were dissolved in distilled water. Electron donor $\left(\mathrm{Na}_{2} \mathrm{~S} \cdot 9 \mathrm{H}_{2} \mathrm{O}\right)$ and acceptor $\left(\mathrm{HNO}_{3}\right)$ were fed from separate bottles to prevent contamination and reactions in the feed bottles (Figure 1).

Table 1. Feeding parameters.

\begin{tabular}{cccc}
\hline Time (Day) & N/S Ratio & $\mathbf{N O}^{-}{ }^{-}(\mathbf{m M} / \mathrm{L})$ & $\mathbf{H S}^{-}(\mathbf{m M} / \mathrm{L})$ \\
\hline $1-30$ & 0.35 & 1.08 & \\
$31-44$ & 0.40 & 1.25 & 3.12 \\
$45-52$ & 0.60 & 1.87 & \\
$53-60$ & 1.30 & 4.05 & \\
\hline
\end{tabular}




\subsection{Experimental Setup}

The $0.5 \mathrm{~L}$ effective volume laboratory-scale EGSB reactor was made of polycarbonate with an inner diameter of $32 \mathrm{~mm}$ and $620 \mathrm{~mm}$ effective height (Figure 1), equipped with tape measure for visual sludge bed height monitoring. Reactor temperature was maintained constant at $10 \pm 0.1^{\circ} \mathrm{C}$ by a cold plate cooler on the recirculation loop (TE Technology, Inc., Traverse City, MI, USA). Four different N/S ratios were tested under invariable temperature and sulfur load imposed according to Table 1.

Synthetic influent was introduced from two $2 \mathrm{~L}$ influent vessels under nitrogen gas to avoid influent aging. Influent was pumped into the reactor at $2 \mathrm{~L} /$ day, equivalent to $6 \mathrm{~h}$ hydraulic retention time. Recycling pump (P3 in Figure 1) was set to maintain $6 \mathrm{~m} / \mathrm{h}$ reactor up-flow velocity necessary to expand the sludge bed. $\mathrm{pH}$ was monitored by electrode (Hanna Instruments) on the recirculation loop.

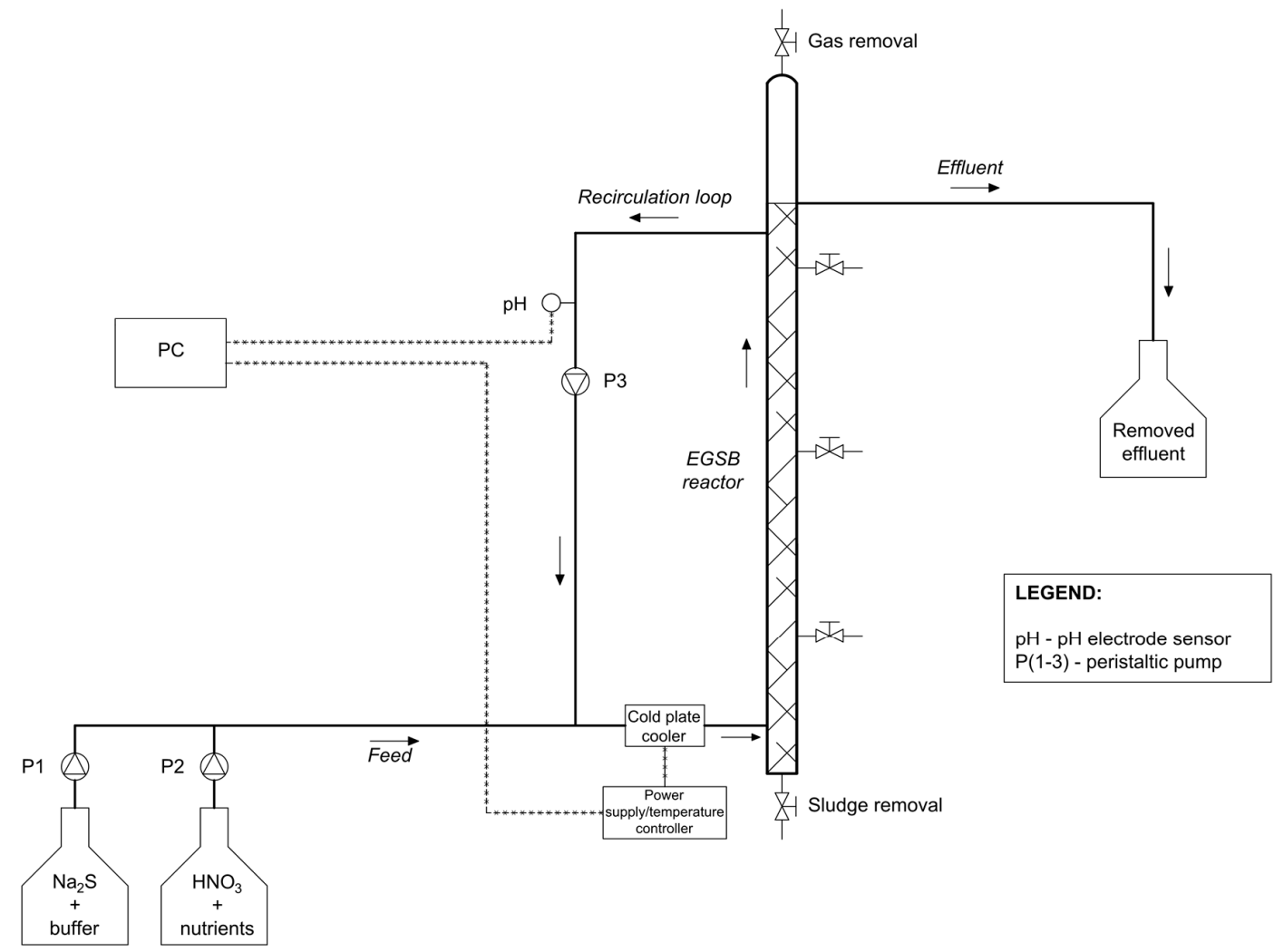

Figure 1. Experimental setup.

\subsection{Analytical Procedure}

Effluent samples were collected daily and analyzed immediately for nitrate $\left(\mathrm{NO}_{3}{ }^{-}\right)$, nitrite $\left(\mathrm{NO}_{2}{ }^{-}\right)$, sulfate $\left(\mathrm{SO}_{4}{ }^{2-}\right)$, sulfide $\left(\mathrm{HS}^{-}\right)$, and thiosulfate $\left(\mathrm{S}_{2} \mathrm{O}_{3}{ }^{2-}\right)$ in collected liquid samples (following $0.45 \mu \mathrm{m}$ filtration) by ion chromatography (Dionex ICS-5000) using potassium hydroxide (KOH) as the eluent. Sulfide concentration was determined indirectly by potassium permanganate oxidation $\left(\mathrm{KMnO}_{4}\right)$. Sample separation and elution was performed using an IonPac AS11-HC $2 \mathrm{~mm}$ analytical column. Analysis started at $22 \mathrm{mM} \mathrm{KOH}$, gradient started at $6 \mathrm{~min}$, ramped up in $3 \mathrm{~min}$ to $45 \mathrm{mM}$ and kept at that concentration for another $4 \mathrm{~min}$. The data acquisition time is $13 \mathrm{~min}$. The injection volume was $10 \mu \mathrm{L}$ and the flow rate $0.3 \mathrm{~mL} / \mathrm{min}$.

\subsection{Elemental Sulfur Measurements}

Two different fractions of $S^{0}$ were distinguished according to Sposob et al. [15]: accumulated into reactor (denoted as $S^{0}$ acc) and suspended elemental sulfur $\left(\mathrm{S}^{0}{ }_{\mathrm{ss}}\right)$. Distinguishing between these two $\mathrm{S}^{0}$ 
fractions is done based on the elemental sulfur balance as an indirect method for quantification of $\mathrm{S}^{0}$ acc, while $\mathrm{S}_{\text {ss }}^{0}$ is equivalent to measured $\mathrm{S}_{2} \mathrm{O}_{3}{ }^{2-}$ [15]. Concentration of $\mathrm{S}^{0}$ acc was calculated based on the difference between influent $\mathrm{HS}^{-}$concentration and effluent concentrations of $\mathrm{HS}^{-}, \mathrm{SO}_{4}{ }^{2-}$, and $\mathrm{S}^{0}{ }_{\mathrm{ss}}$, according to Equation (1). $\mathrm{H}_{2} \mathrm{~S}$ in the headspace was not measured.

$$
\mathrm{S}^{0}{ }_{\mathrm{acc}}=\mathrm{HS}^{-}{ }_{\text {inf }}-\mathrm{HS}^{-}{ }_{\text {eff }}-\mathrm{SO}_{4}{ }^{2-}{ }_{\text {eff }}-\mathrm{S}^{0}{ }_{\mathrm{ss}}
$$

\section{Results and Discussion}

\subsection{Reactor Performance}

The electron acceptor was almost completely removed (Figure 2), on average $98.7 \pm 2.8 \%$ throughout the 60 days experiment, which consisted of four phases with increasing $\mathrm{NO}_{3}{ }^{-}$ concentration, thereby changing $\mathrm{N} / \mathrm{S}$ ratio (Table 1 ). The $\mathrm{NO}_{3}{ }^{-}$removal was equal to $96.8 \pm 3.9 \%$ at the highest $\mathrm{N} / \mathrm{S}$ ratio and $99.3 \pm 2.3 \%$ at the lowest ratio. It has been reported that $\mathrm{NO}_{3}{ }^{-}$removal can be significantly inhibited at N/S ratios much higher than derived from stoichiometry [17] but this was not the case here. However, the changes in N/S ratio had an impact on $\mathrm{HS}^{-}$removal with $89.1 \pm 2.2$ and $89.6 \pm 2.9 \%$ at N/S ratios of 0.35 and 1.30 , respectively, and only $76.9 \pm 2.6 \%$ at N/S $=0.60$ (Figure 2).

Both $\mathrm{S}^{0}$ forms, accumulated $\left(\mathrm{S}^{0}\right.$ acc $)$ and suspended $\left(\mathrm{S}^{0}{ }_{\mathrm{ss}}\right)$, were decreasing with increasing N/S ratios and they were negligible at $\mathrm{N} / \mathrm{S}=1.30$ (Table 2). The negative $\mathrm{S}^{0}$ acc value at $\mathrm{N} / \mathrm{S}=1.30$ implies the oxidation to $\mathrm{SO}_{4}{ }^{2-}$ of the earlier accumulated $\mathrm{S}^{0}$ in the reactor during lower $\mathrm{N} / \mathrm{S}$ ratios.

Each increase in $\mathrm{NO}_{3}{ }^{-}$resulted in $\mathrm{SO}_{4}{ }^{2-}$ concentration rise, depletion of $\mathrm{S}^{0}$ fractions and $\mathrm{pH}$ drop (Figures 3 and 4). During the last week of the experiment, $\mathrm{pH}$ decreased to $7.19 \pm 0.31$ at N/S=1.30 due to high $\mathrm{SO}_{4}{ }^{2-}$ production (Figures 3 and 4). At this $\mathrm{pH}$, a larger fraction of $\mathrm{HS}^{-}$in the unionized form as $\mathrm{H}_{2} \mathrm{~S}$ could occur compared to the conditions at lower N/S, with higher $\mathrm{pH}$ (Figure 4). It is still argued that an insignificant amount of $\mathrm{H}_{2} \mathrm{~S}$ was stripped off to headspace since: the dissolved $\mathrm{H}_{2} \mathrm{~S}$ level at pH $7.19 \pm 0.31$ is calculated to only $0.2 \mathrm{mM} / \mathrm{L}$ and $\mathrm{H}_{2} \mathrm{~S}$ has a high solubility in water $\left(150 \mathrm{mM} / \mathrm{L}\right.$, at $\left.10^{\circ} \mathrm{C}[18]\right)$. Therefore, there is no unaccounted for or missing sulfur in the balance.

Table 2. Process output parameters (concentrations in $\mathrm{mM} / \mathrm{L}$ ).

\begin{tabular}{|c|c|c|c|c|c|c|c|}
\hline N/S Ratio & $\mathrm{S}_{\text {acc }}{ }^{1}$ & $\mathrm{SO}_{4}{ }^{2-}$ & $\mathrm{S}_{\text {ss }}^{0}$ & $\mathrm{HS}^{-}-\mathrm{S}$ & $\mathrm{NO}_{3}{ }^{-}$ & $\mathrm{pH}$ & Total Sulfur (Effluent) $^{2}$ \\
\hline 0.40 & $0.44 \pm 0.32$ & $0.96 \pm 0.21$ & $1.24 \pm 0.16$ & $0.56 \pm 0.15$ & $0.02 \pm 0.03$ & $7.92 \pm 0.15$ & $2.76 \pm 0.36$ \\
\hline 1.30 & $-0.69 \pm 0.58$ & $3.37 \pm 0.83$ & $0.11 \pm 0.23$ & $0.32 \pm 0.09$ & $0.15 \pm 0.16$ & $7.19 \pm 0.31$ & $3.81 \pm 0.58$ \\
\hline
\end{tabular}

Notes: ${ }^{1}$ Derived values come from the balance (Equation (1)); ${ }^{2}$ Total sulfur (effluent) $=\mathrm{SO}_{4}{ }^{2-}+\mathrm{S}_{\mathrm{ss}}^{0}+\mathrm{HS}^{-}-\mathrm{S}$.

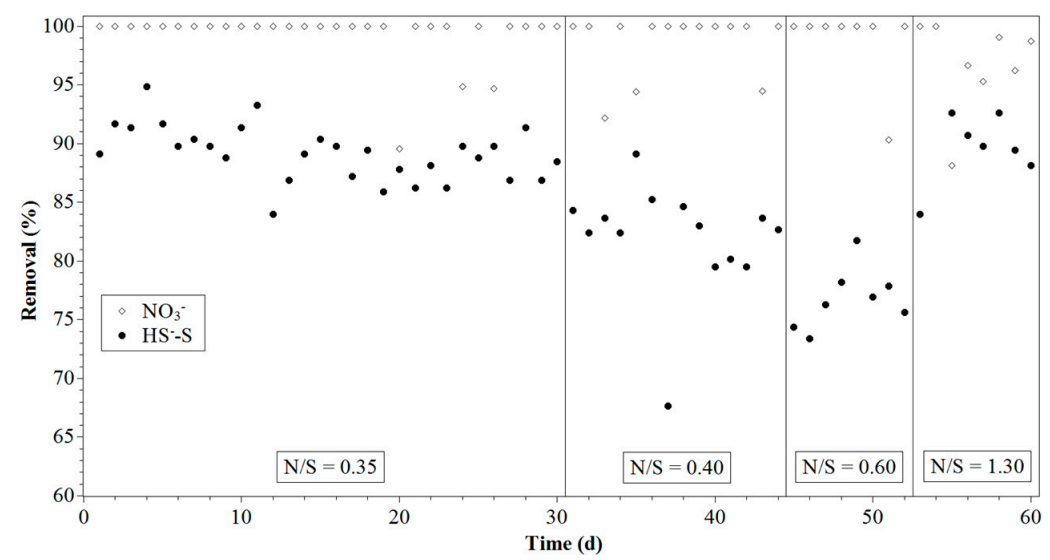

Figure 2. Time series of substrates removal $\left(\mathrm{NO}_{3}{ }^{-}\right.$and $\left.\mathrm{HS}^{-}\right)$under different $\mathrm{N} / \mathrm{S}$ ratios at $10{ }^{\circ} \mathrm{C}$. 


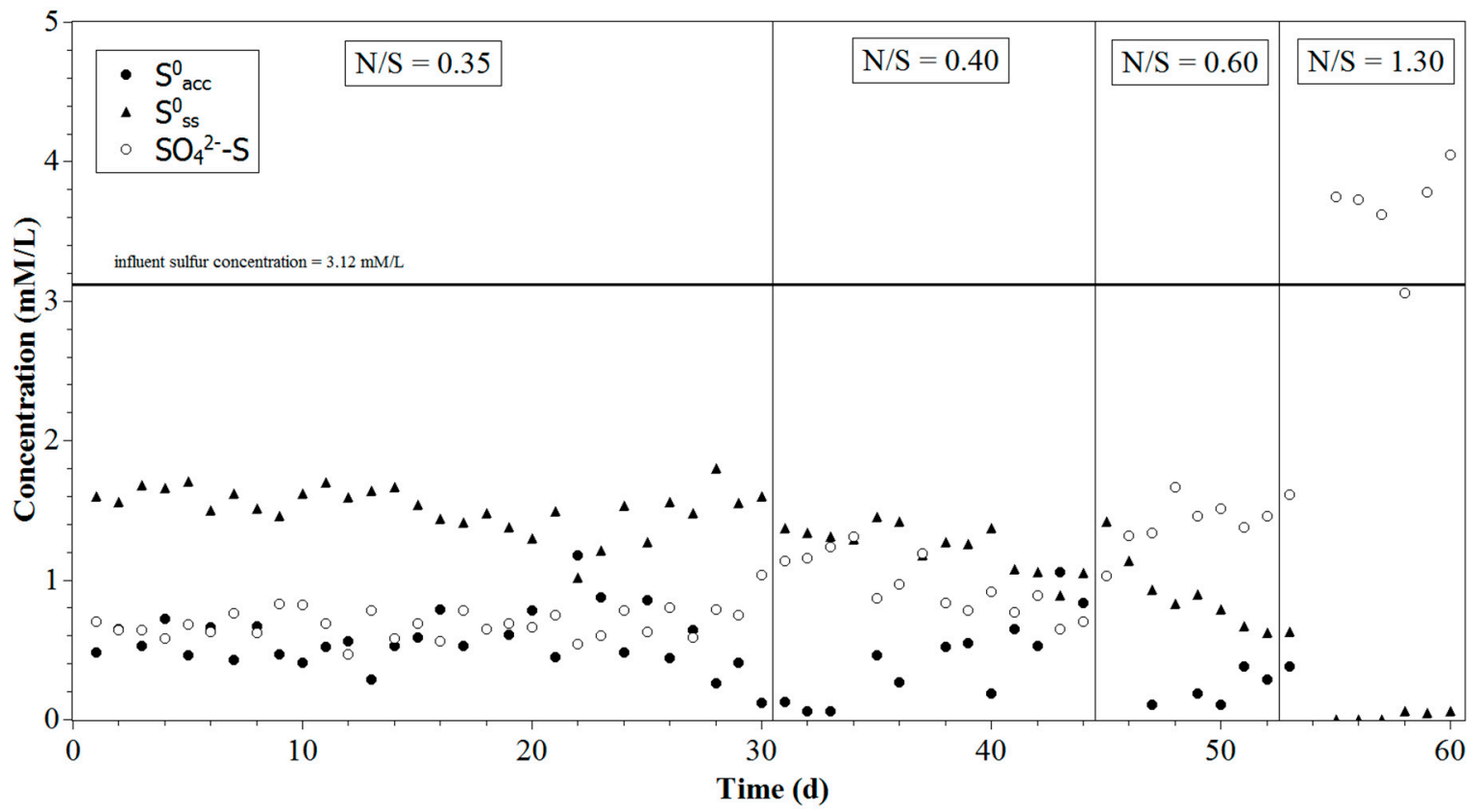

Figure 3. Time series of accumulated $\left(\mathrm{S}^{0}\right.$ acc $)$ and suspended $\left(\mathrm{S}^{0}{ }_{\mathrm{ss}}\right)$ elemental sulfur, and sulfate $\left(\mathrm{SO}_{4}{ }^{2-}-\mathrm{S}\right)$ concentrations under different $\mathrm{N} / \mathrm{S}$ ratios at $10{ }^{\circ} \mathrm{C}$.

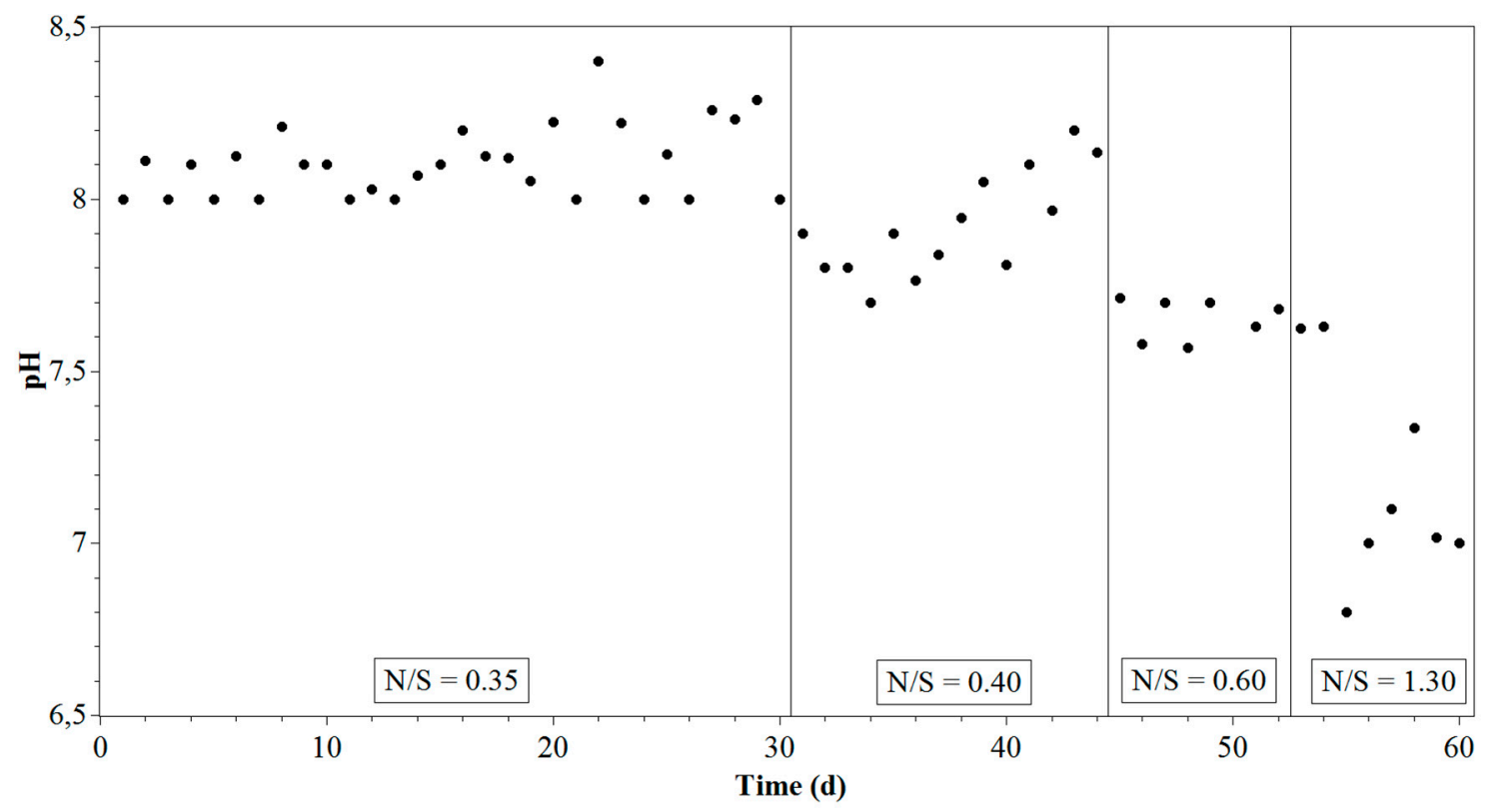

Figure 4. $\mathrm{pH}$ vs. time under different $\mathrm{N} / \mathrm{S}$ ratios at $10{ }^{\circ} \mathrm{C}$.

\subsection{Sulfur Components at Different N/S Ratios}

The imposed increase in feed $\mathrm{NO}_{3}{ }^{-}$concentration had, as expected, an impact on the presence of the four different sulfur components, $\mathrm{HS}^{-}, \mathrm{SO}_{4}{ }^{2-}$ and two fractions of $\mathrm{S}^{0}$ : accumulated $\left(\mathrm{S}^{0}\right.$ acc $)$ and suspended $\left(\mathrm{S}^{0}{ }_{\mathrm{ss}}\right)$ (Figure 5). 


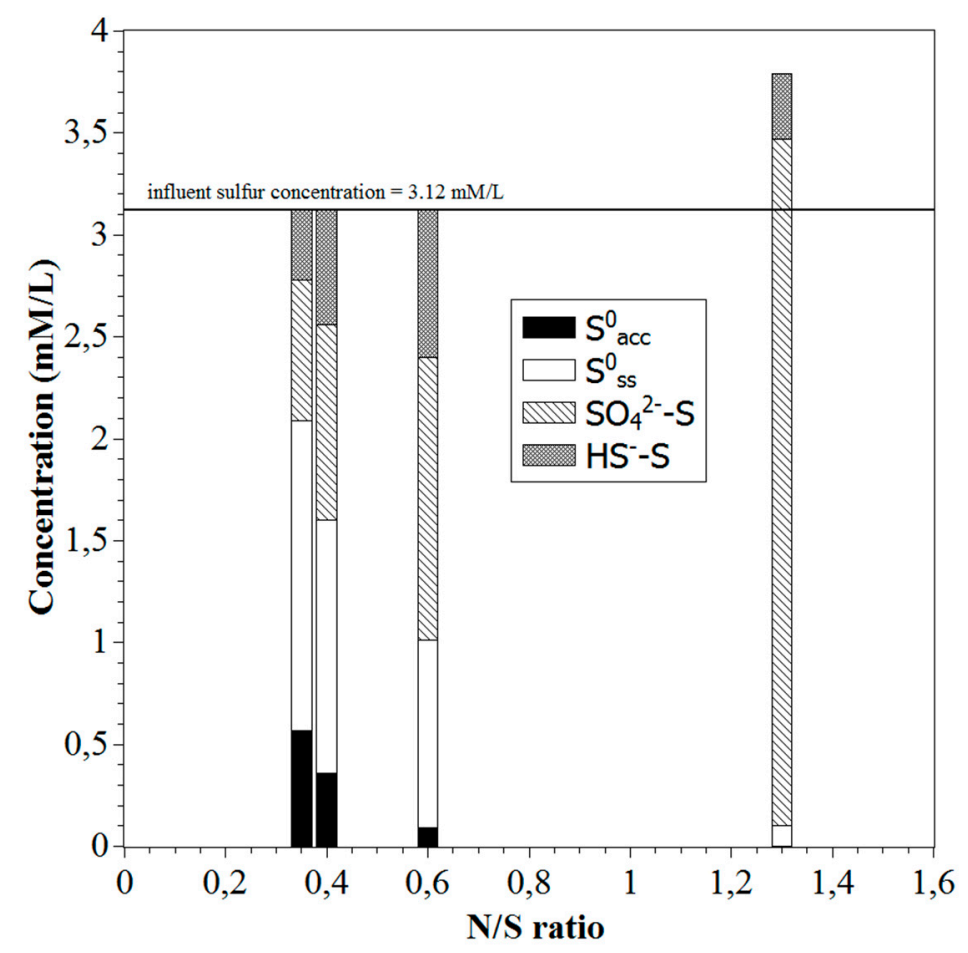

Figure 5. Share of sulfur products under different $\mathrm{N} / \mathrm{S}$ ratios at $10{ }^{\circ} \mathrm{C}$.

The initially tested N/S ratio revealed that around $11 \%(0.34 \pm 0.07 \mathrm{mM} / \mathrm{L})$ of influent sulfur remained unreacted as $\mathrm{HS}^{-}$. At this condition, $\mathrm{S}_{\text {ss }}^{0}$ was a main fraction of $\mathrm{S}^{0}$ at a $49 \%$ share of influent sulfur while $\mathrm{S}_{\text {acc }}^{0}$ constituted $18 \%$, adding up to $67 \%$. A share of $22 \%$ of the electron donor was oxidized to $\mathrm{SO}_{4}{ }^{2-}$ at $\mathrm{N} / \mathrm{S}=0.35$. Similar studies performed at mesophilic conditions reveal lower $\mathrm{SO}_{4}{ }^{2-}$ fractions at similar N/S ratio: (1) At $25^{\circ} \mathrm{C}$ and N/S $=0.35$ the fraction of $\mathrm{SO}_{4}{ }^{2-}$ constituted $14 \%$ [15]; (2) At room temperature $\left(22-23{ }^{\circ} \mathrm{C}\right)$ and N/S $=0.32$ only $4 \%$ of $\mathrm{HS}^{-}$was converted to $\mathrm{SO}_{4}{ }^{2-}$ [19]. The results confirm previous studies that show temperature impact on $\mathrm{HS}^{-}$removal and $\mathrm{SO}_{4}{ }^{2-}$ production, where the $\mathrm{SO}_{4}{ }^{2-}$ share increases with decreasing temperature [15].

The slight increase in N/S ratio from 0.35 to 0.40 (equivalent to catabolic reaction in simultaneous $\mathrm{NO}_{3}{ }^{-}$and $\mathrm{HS}^{-}$removal to yield $\mathrm{S}^{0}$ ) was imposed to supply sufficient $\mathrm{NO}_{3}{ }^{-}$such to obtain the complete removal of $\mathrm{HS}^{-}$, it however led to less $\mathrm{HS}^{-}$oxidation. The presence of $\mathrm{S}^{0}$ fractions also decreased from 67 to $54 \%$, reducing the concentration of $\mathrm{S}^{0}$ acc by $23 \%$ and $\mathrm{S}^{0}$ ss by $18 \%$ in comparison to the previous $(\mathrm{N} / \mathrm{S}=0.35$ ) period (Table 2$)$. The electron donor removal decreased, so that $18 \%$ of influent sulfur remained unreacted. More of the $\mathrm{HS}^{-}$oxidized was, however, oxidized to the highest oxidation level (+VI), increasing the $\mathrm{SO}_{4}{ }^{2-}$ share of products from 22 to $31 \%$. This clearly shows that the appropriate $\mathrm{N} / \mathrm{S}$ ratio for $\mathrm{S}^{0}$ production is lower than that reflected in the catabolic reaction alone.

$\mathrm{S}^{0}{ }_{\text {acc }}$ was almost completely avoided at $\mathrm{N} / \mathrm{S}=0.60$ ( $3 \%$ of influent sulfur, Figure 5$) . \mathrm{S}^{0}$ was still present in the liquid phase $\left(\mathrm{S}^{0}{ }_{\mathrm{ss}}=29 \%\right.$ of influent sulfur) but much less than at lower $\mathrm{N} / \mathrm{S}$ ratios. Concentration of $\mathrm{HS}^{-}$and $\mathrm{SO}_{4}{ }^{2-}$ at the effluent increased compared to lower N/S ratios. Unreacted $\mathrm{HS}^{-}, 23 \%, 0.72 \pm 0.08 \mathrm{mM} / \mathrm{L}$, shows the lowest removal of electron donor during the whole experiment. The increase in $\mathrm{SO}_{4}{ }^{2-}$ was similar as for the transition from 0.35 to 0.40 , at N/S $=0.60$ had a share of $45 \%$.

Effluent $\mathrm{SO}_{4}{ }^{2-}$ was the main $\mathrm{HS}^{-}$oxidation product at the highest studied N/S ratio (1.30; $\left.\mathrm{NO}_{3}{ }^{-}=4.08 \mathrm{mM} / \mathrm{L}\right)$ but its concentration varied more than at lower $\mathrm{N} / \mathrm{S}(3.37 \pm 0.83 \mathrm{mM} / \mathrm{L})$. The sum of sulfur components in the effluent was $22 \%$ higher than in the influent during this period (Figures 3 and 5), which is explained by the oxidation of previously accumulated sulfur, $\mathrm{S}^{0}$ acc. Similar behavior has been observed during abrupt temperature drops [20]. The slight amount $\mathrm{S}^{0}{ }_{\mathrm{ss}}(0.11 \pm 0.23 \mathrm{mM} / \mathrm{L}$; 
$4 \%$ ) observed in this period is assumed to originate from previously accumulated sulfur, $\mathrm{S}^{0}$ acc. Excess effluent compared to influent sulfur must have a temporary nature until the $\mathrm{S}^{0}$ acc in granules is exhausted but the experiment did not last long enough to reach such a steady state.

The observed substrate consumption and products distribution for different ratios between electron acceptor and donor differs from that reported based on catabolic reactions under mesophilic conditions. In comparison, nitrite $\left(\mathrm{NO}_{2}{ }^{-}\right)$accumulation observed under mesophilic conditions [7] did not occur in the presented work. It has also been reported that SOB like Thiobacillus denitrificans oxidizes stored sulfur only when reduced sulfur compounds-i.e., $\mathrm{S}_{2} \mathrm{O}_{3}{ }^{2-}$-have been depleted [21]. However, in this study higher $\mathrm{NO}_{3}{ }^{-}$immediately triggered $\mathrm{a} \mathrm{SO}_{4}{ }^{2-}$ production increase even when HS $^{-}$was not completely oxidized.

It has been reported that changes in N/S ratio under heterotrophic conditions caused changes in products distribution similar to that observed here. Additionally, changes in N/S ratio led to changes in the heterotrophic microbial community structure [22]. There may similarly have been autotrophic community changes in the present study, but this was not investigated. An observed decrease in sludge bed height level by $58 \%$ from the lowest to the highest N/S tested here may have been related to microbial community structure changes but the main cause is probably loss of $\mathrm{S}^{0}$ acc from the granules. Oxidation of initially stored $S^{0}$ acc to recover energy at high N/S ratios, is proposed as the main cause of sludge bed reduction.

\subsection{Relation between Experimental and Theoretical Products Distribution}

Using N/S ratio as a way to control the fate of $\mathrm{HS}^{-}$oxidation to either $\mathrm{S}^{0}$ and /or $\mathrm{SO}_{4}{ }^{2-}$ [9] is further analyzed by comparing theoretical equations [6] and experimental results (Figure 6). Obtained experimental results show the offset from theoretical values with good match only at $\mathrm{N} / \mathrm{S}=1.30$. The observed offset, especially at $\mathrm{N} / \mathrm{S}=0.35$, may be due to a metabolic shift that has been observed in a temperature impact study [15]. It was observed that the production of $\mathrm{SO}_{4}{ }^{2-}$ was increasing at a constant N/S ratio $(=0.35)$ with decreasing temperature, which was hypothesized to be a natural response of microbiota to compensate temperature-induced changes in energy requirements.
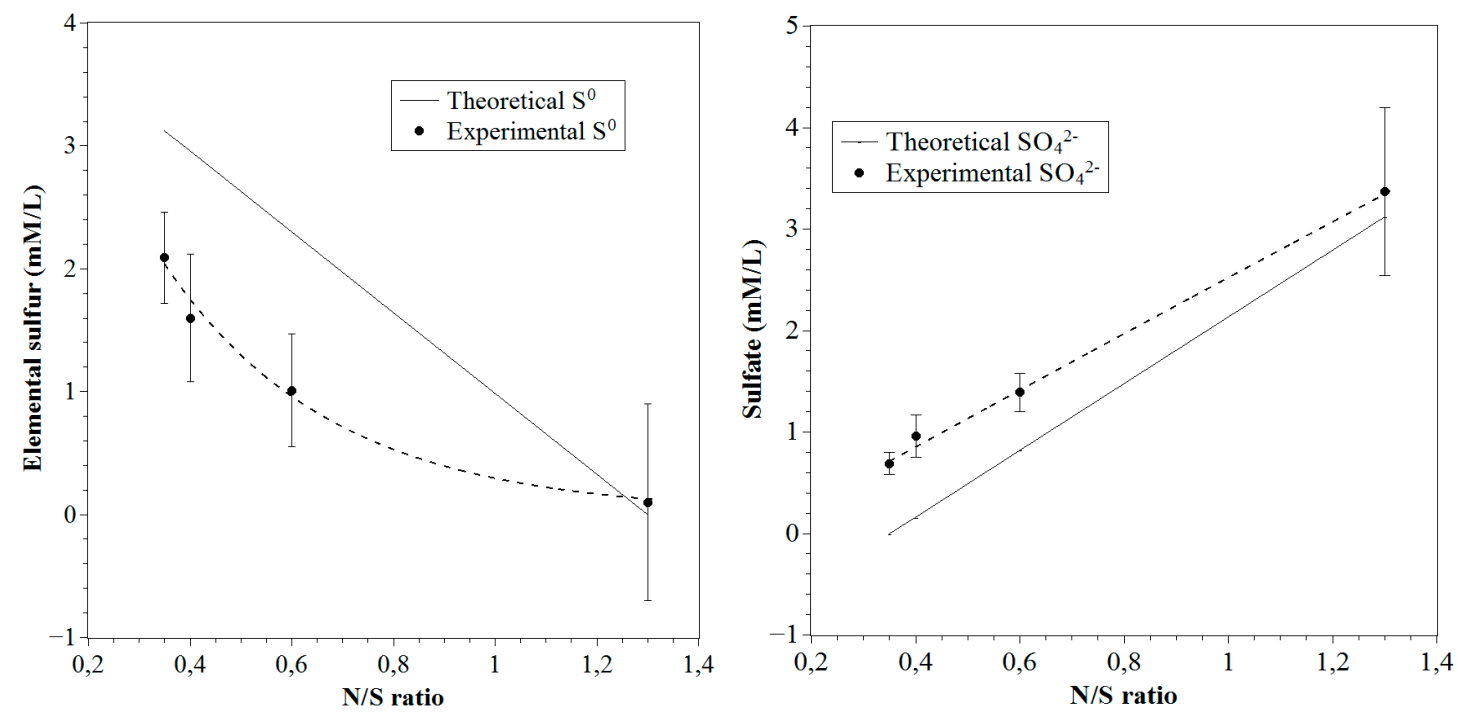

Figure 6. Experimental and theoretical concentration of elemental sulfur $\left(\mathrm{S}^{0}{ }_{\text {acc }}+\mathrm{S}^{0}{ }_{\mathrm{ss}}\right)(\mathbf{l e f t})$, and $\mathrm{SO}_{4}^{2-}$ (right).

Theoretically, according to the equations given by Kleerebezem and Mendez [6], equal product distribution between $\mathrm{S}^{0}$ and $\mathrm{SO}_{4}{ }^{2-}$ should be expected at $\mathrm{N} / \mathrm{S}=0.825$ or even at higher ratios, taking into account just the catabolic reactions. Experimentally, however, equal distribution of $S^{0}$ and 
$\mathrm{SO}_{4}{ }^{2-}$ was reached already at $\mathrm{N} / \mathrm{S}=0.6$. The organisms accumulated some amount of sulfur, $\mathrm{S}^{0}$ acc, as an energy reserve at low N/S ratio. Thus, in addition to temperature effects, the obtained offset at $\mathrm{N} / \mathrm{S}$ ratios 0.4 and 0.6 may have been influenced by the oxidation of $\mathrm{S}^{0}{ }_{\text {acc. }}$. The continuous flow feeding with increasing N/S ratio, facilitated the observation of competition between $\mathrm{S}_{\text {acc }}^{0}$ and $\mathrm{HS}^{-}$as electron donors. This is especially visible at mid-N/S ratios where the $S^{0}$ acc was evidently, to changing degrees, used as an electron donor together with $\mathrm{HS}^{-}$, for which removal decreased at the same time. This observation contradicts the previous studies in which it has been reported that the oxidation of accumulated $\mathrm{S}^{0}$ as an electron reserve can occur only when the reduced sulfur compounds are depleted (HS ${ }^{-}$in this case) [21]. The possibility that the organisms can utilize this stored energy by oxidizing $\mathrm{S}^{0}{ }_{\text {acc }}$ to $\mathrm{SO}_{4}{ }^{2-}$ also in conditions when surplus $\mathrm{HS}^{-}$is present implies larger culture flexibility to utilize available resources. The microorganisms may thereby have increased their catabolic energy yield by utilizing differences in free Gibbs energy since the oxidation from $\mathrm{S}^{0}$ to $\mathrm{SO}_{4}{ }^{2-}$ has a slightly higher $\Delta \mathrm{G}^{\circ}$ than from $\mathrm{HS}^{-}$to $\mathrm{SO}_{4}{ }^{2-},-800.76$ and $-768.28 \mathrm{~kJ} /$ reaction, respectively (Table 3 ). The exponential-like response for $\mathrm{S}^{0}$ (Figure 6) may thereby be a result of increased $\mathrm{S}^{0}$ acc oxidation with increased influent $\mathrm{NO}_{3}{ }^{-}$concentration. This pathway apparently has an impact and may explain the offset and shape of the exponential-like response of $\mathrm{N} / \mathrm{S}$ ratio on $\mathrm{S}^{0}$.

Table 3. Possible reaction of sulfur reduced compounds with nitrate $\left(\mathrm{NO}_{3}{ }^{-}\right)$.

\begin{tabular}{cc}
\hline Reaction & $\Delta \mathbf{G}^{\circ} \mathbf{( 1 \mathbf { M } \text { of Electron Donor) }}$ \\
\hline $\mathrm{HS}^{-}+0.4 \mathrm{NO}_{3}{ }^{-}+1.4 \mathrm{H}^{+} \rightarrow \mathrm{S}^{0}+0.2 \mathrm{~N}_{2}+1.2 \mathrm{H}_{2} \mathrm{O}$ & -252.13 \\
$\mathrm{HS}^{-}+0.8 \mathrm{NO}_{3}{ }^{-}+0.8 \mathrm{H}^{+} \rightarrow 0.5 \mathrm{~S}_{2} \mathrm{O}_{3}{ }^{2-}+0.4 \mathrm{~N}_{2}+0.9 \mathrm{H}_{2} \mathrm{O}$ & -393.14 \\
$\mathrm{HS}^{-}+1.6 \mathrm{NO}_{3}{ }^{-}+0.6 \mathrm{H}^{+} \rightarrow \mathrm{SO}_{4}{ }^{2-}+0.8 \mathrm{~N}_{2}+0.8 \mathrm{H}_{2} \mathrm{O}$ & -768.28 \\
$\mathrm{~S}^{0}+1.2 \mathrm{NO}_{3}{ }^{-}+0.4 \mathrm{H}_{2} \mathrm{O} \rightarrow \mathrm{SO}_{4}{ }^{2-}+0.6 \mathrm{~N}_{2}+0.8 \mathrm{H}_{2} \mathrm{O}$ & -800.76 \\
\hline
\end{tabular}

The overall percentage distribution of reactants and products (Table 4) shows an imbalance of electrons in the experimental data which implies that some $\mathrm{SO}_{4}{ }^{2-}$ must have been produced through the use of an electron acceptor other than $\mathrm{NO}_{3}{ }^{-}$. The percentage of influent sulfur (as HS${ }^{-}$) oxidized by another electron acceptor decreased with increasing N/S ratio from 14 to $8 \%$ of influent sulfur. Similar observations have been reported in other studies where the obtained products exceeds what is theoretically expected based on fed electron acceptor $[7,15]$. Such unintended electron acceptors could be $\mathrm{H}^{+}$to give $\mathrm{H}_{2}$ gas, inorganic carbon to biomass, or exposure to $\mathrm{O}_{2}$.

Table 4. Comparison of theoretical and experimental percentage share of products and electron acceptors uptake.

\begin{tabular}{|c|c|c|c|c|c|c|c|}
\hline \multirow{2}{*}{$\begin{array}{l}\text { N/S } \\
\text { Ratio }\end{array}$} & \multicolumn{2}{|c|}{ Theoretical Share (\%) } & \multicolumn{2}{|c|}{ Experimental Share (\%) } & \multicolumn{2}{|c|}{$\mathrm{NO}_{3}{ }^{-}$Uptake Share (\%) } & \multirow{2}{*}{$\begin{array}{l}\mathrm{SO}_{4}{ }^{2-} \text { Produced by Another } \\
\text { Electron Acceptor }(\mathrm{mM} / \mathrm{L})\end{array}$} \\
\hline & $\mathrm{S}^{0}$ & $\mathrm{SO}_{4}{ }^{2-}$ & $S^{0}$ & $\mathrm{SO}_{4}{ }^{2-}$ & $\mathrm{S}^{0}$ & $\mathrm{SO}_{4}^{2-}$ & \\
\hline 0.35 & 100 & 0 & 67 & 22 & 67 & 33 & $0.41(13 \%)^{1}$ \\
\hline 0.60 & 74 & 26 & 32 & 45 & 18 & 82 & $0.22(7 \%)$ \\
\hline 1.30 & 0 & 100 & $4^{2}$ & 108 & 1 & 99 & $0.26(8 \%)$ \\
\hline
\end{tabular}

\section{Conclusions}

The lowest and highest N/S ratios, 0.35 and 1.30, did not differ in $\mathrm{HS}^{-}$removal, with $89.1 \pm 2.2 \%$ and $89.6 \pm 2.9 \%$, respectively. Less $\mathrm{HS}^{-}$removal was obtained at intermediate $\mathrm{N} / \mathrm{S}$ ratios with the lowest, $76.9 \pm 2.6 \%$, at $\mathrm{N} / \mathrm{S}=0.60$.

The products from the studied N/S ratios deviated from theoretical predictions, except at $\mathrm{N} / \mathrm{S}=1.30$. Additionally, equal product distribution between $\mathrm{S}^{0}$ and $\mathrm{SO}_{4}{ }^{2-}$ occurred at a lower $\mathrm{N} / \mathrm{S}$ ratio than theoretically expected. This implies that the reactions in continuous flow bioreactors are more complicated than accounted for in standard stoichiometric models. 
Increasing $\mathrm{N} / \mathrm{S}$ feed ratio caused an increase in $\mathrm{SO}_{4}{ }^{2-}$ production and depletion of stored $\mathrm{S}^{0}$. The $\mathrm{S}^{0}$ accumulated during the low $\mathrm{N} / \mathrm{S}$ feed ratio was utilized at higher $\mathrm{N} / \mathrm{S}$, thus, leading to $\mathrm{SO}_{4}{ }^{2-}$ production to recover stored energy. The oxidation of $S^{0}$ occurred even though excess HS $^{-}$was available at higher feed N/S ratios $(>0.35)$. These phenomena can explain the lower removal of $\mathrm{HS}^{-}$at mid-N/S ratios and the highest sulfur concentration obtained in the effluent at $\mathrm{N} / \mathrm{S}=1.30$.

Efficient psychrophilic biological $\mathrm{HS}^{-}$removal with $\mathrm{NO}_{3}{ }^{-}$as an electron acceptor in an EGSB process is documented and elemental sulfur $\left(\mathrm{S}^{0}\right)$ harvesting can be obtained through careful $\mathrm{NO}_{3}{ }^{-}$ supply control.

Acknowledgments: The authors would like to thank YARA AS International and The Research Council of Norway for support of this research.

Author Contributions: Carlos Dinamarca and Michal Sposob conceived and designed the experiment and all authors were involved in analyzing the data; Michal Sposob performed the experiments and analyzed all the samples; Michal Sposob, Rune Bakke and Carlos Dinamarca contributed to writing the paper.

Conflicts of Interest: The authors declare no conflict of interest.

\section{References}

1. Pokorna, D.; Zabranska, J. Sulfur-oxidizing bacteria in environmental technology. Biotechnol. Adv. 2015, 33, 1246-1259. [CrossRef] [PubMed]

2. Chen, Y.; Cheng, J.J.; Creamer, K.S. Inhibition of anaerobic digestion process: A review. Bioresour. Technol. 2008, 99, 4044-4064. [CrossRef] [PubMed]

3. Zhou, Z.; Yu, Z.; Meng, Q. Effects of nitrate on methane production, fermentation, and microbial populations in in vitro ruminal cultures. Bioresour. Technol. 2012, 103, 173-179. [CrossRef] [PubMed]

4. Knoblauch, C.; Sahm, K.; Jørgensen, B.B. Psychrophilic sulfate-reducing bacteria isolated from permanently cold Arctic marine sediments: Description of Desulfofrigus oceanense gen. nov., sp. nov., Desulfofrigus fragile sp. nov., Desulfofaba gelida gen. nov., sp. nov., Desulfotalea psychrophila gen. nov., sp. nov. and Desulfotalea arctica sp. nov. Int. J. Syst. Evol. Microbiol. 1999, 49, 1631-1643.

5. Auguet, O.; Pijuan, M.; Borrego, C.M.; Gutierrez, O. Control of sulfide and methane production in anaerobic sewer systems by means of Downstream Nitrite Dosage. Sci. Total Environ. 2016, 550, 1116-1125. [CrossRef] [PubMed]

6. Kleerebezem, R.; Mendez, R. Autotrophic denitrification for combined hydrogen sulfide removal from biogas and post-denitrification. Water Sci. Technol. 2002, 45, 349-356. [PubMed]

7. Cai, J.; Zheng, P.; Mahmood, Q. Effect of sulfide to nitrate ratios on the simultaneous anaerobic sulfide and nitrate removal. Bioresour. Technol. 2008, 99, 5520-5527. [CrossRef] [PubMed]

8. Fajardo, C.; Mora, M.; Fernández, I.; Mosquera-Corral, A.; Campos, J.L.; Méndez, R. Cross effect of temperature, $\mathrm{pH}$ and free ammonia on autotrophic denitrification process with sulphide as electron donor. Chemosphere 2014, 97, 10-15. [CrossRef] [PubMed]

9. Beristain-Cardoso, R.; Sierra-Alvarez, R.; Rowlette, P.; Flores, E.R.; Gómez, J.; Field, J.A. Sulfide oxidation under chemolithoautotrophic denitrifying conditions. Biotechnol. Bioeng. 2006, 95, 1148-1157. [CrossRef] [PubMed]

10. Huang, C.; Li, Z.; Chen, F.; Liu, Q.; Zhao, Y.; Gao, L.; Chen, C.; Zhou, J.; Wang, A. Efficient regulation of elemental sulfur recovery through optimizing working height of upflow anaerobic sludge blanket reactor during denitrifying sulfide removal process. Bioresour. Technol. 2016, 200, 1019-1023. [CrossRef] [PubMed]

11. Mahmood, Q.; Zheng, P.; Cai, J.; Wu, D.; Hu, B.; Li, J. Anoxic sulfide biooxidation using nitrite as electron acceptor. J. Hazard. Mater. 2007, 147, 249-256. [CrossRef] [PubMed]

12. Xu, Y.; Chen, N.; Feng, C.; Hao, C.; Peng, T. Sulfur-based autotrophic denitrification with eggshell for nitrate-contaminated synthetic groundwater treatment. Environ. Technol. 2016, 37, 3094-3103. [CrossRef] [PubMed]

13. Di Capua, F.; Milone, I.; Lakaniemi, A.M.; Lens, P.N.L.; Esposito, G. High-rate autotrophic denitrification in a fluidized-bed reactor at psychrophilic temperatures. Chem. Eng. J. 2017, 313, 591-598. [CrossRef]

14. Yamamoto-Ikemoto, R.; Komori, T.; Nomuri, M.; Ide, Y.; Matsukami, T. Nitrogen removal from hydroponic culture wastewater by autotrophic denitrification using thiosulfate. Water Sci. Technol. 2000, 42, 369-376. 
15. Sposob, M.; Bakke, R.; Dinamarca, C. Metabolic divergence in simultaneous biological removal of nitrate and sulfide for elemental sulfur production under temperature stress. Bioresour. Technol. 2017, 233, 209-215. [CrossRef] [PubMed]

16. Wolin, E.A.; Wolin, M.J.; Wolfe, R.S. Formation of methane by bacterial extracts. J. Biol. Chem. 1963, 238, 2882-2886. [PubMed]

17. Oh, S.E.; Kim, K.S.; Choi, H.C.; Cho, J.; Kim, I.S. Kinetics and physiological characteristics of autotrophic dentrification by denitrifying sulfur bacteria. Water Sci. Technol. 2000, 42, 59-68.

18. Carroll, J.J.; Mather, A.E. The solubility of hydrogen sulphide in water from 0 to $90{ }^{\circ} \mathrm{C}$ and pressures to $1 \mathrm{MPa}$. Geochim. Cosmochim. Acta 1989, 53, 1163-1170. [CrossRef]

19. An, S.; Tang, K.; Nemati, M. Simultaneous biodesulphurization and denitrification using an oil reservoir microbial culture: Effects of sulphide loading rate and sulphide to nitrate loading ratio. Water Res. 2010, 44, 1531-1541. [CrossRef] [PubMed]

20. Sposob, M.; Dinamarca, C.; Bakke, R. Short-term temperature impact on simultaneous biological nitrogen-sulphur treatment in EGSB reactor. Water Sci. Technol. 2016, 74, 1610-1618. [CrossRef] [PubMed]

21. Schedel, M.; Trüper, H.G. Anaerobic oxidation of thiosulfate and elemental sulfur in Thiobacillus denitrificans. Arch. Microbiol. 1980, 124, 205-210. [CrossRef]

22. Chen, C.; Xu, X.J.; Xie, P.; Yuan, Y.; Zhou, X.; Wang, A.J.; Lee, D.J.; Ren, N.Q. Pyrosequencing reveals microbial community dynamics in integrated simultaneous desulfurization and denitrification process at different influent nitrate concentrations. Chemosphere 2017, 171, 294-301. [CrossRef] [PubMed]

(C) 2017 by the authors. Licensee MDPI, Basel, Switzerland. This article is an open access article distributed under the terms and conditions of the Creative Commons Attribution (CC BY) license (http:/ / creativecommons.org/licenses/by/4.0/). 